\title{
Financial Distress and Bankruptcy Prediction: An empirical analysis of the manufacturing industry in Albania
}

\author{
TEUTA XHINDI \\ Head of the Informatics and Scientific Training Department \\ Mediterranean University of Albania \\ Rr. Todi Shkurti, P.7, Ap.6, Tirana 1010 \\ ALBANIA \\ KEVIN SHESTANI \\ MSc. Student at the University of Turin \\ Via Santa Gulia 10, Turin 10126 \\ ITALY \\ email: kevin.shestani@yahoo.com
}

\begin{abstract}
Bankruptcy is the conclusive affirmation of the inability of a company to support and endure current operations given its current financial position and debt obligations. If bankruptcy could be expected with affordable precision ahead of time, managers and investors of companies may have the possibility to take action to secure their companies, reduce risk and loss of business and perhaps even avoid bankruptcy itself. The aim of this paper is to test the suitability and predictive accuracy of the Altman Z-Score model in the Albanian manufacturing industry. After performing the empirical analysis, the conclusion is that this model clearly fails to effectively predict financial distress and bankruptcy and it isn't reliable in our case. Lastly, a logistic regression model is proposed, which is more adequate for the Albanian context.
\end{abstract}

Key-words: Bankruptcy, financial distress, crisis, manufacturing industry, Z-Score model, logistic regression

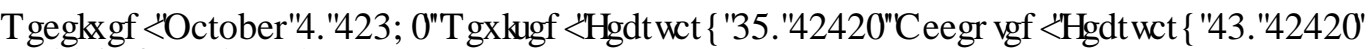

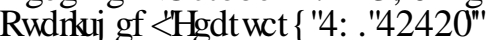

\section{Introduction}

The main focus of this study is the analysis and prediction of financial distress and bankruptcy in the manufacturing sector in Albania. Manufacturing companies are considerably contributing to the economic growth of the country and are regarded as highly important for the Albanian economy. In terms of geographical distribution, most of these companies are located in the capital of the country, Tirana, or nearby big cities like Vlora, Fier, Elbasani, Shkodra. According to Cania et al (2016), the manufacturing industry is concentrated mainly in $20 \%$ to $25 \%$ of the Albanian territory, predominantly in territories in/around Tirana. This sector is mostly oriented towards furniture and textile, footwear, fuel, minerals and electricity. They represent some of the highest employers in the country.

Also, referring to Anamali et al (2015), manufacturing companies typically offer low paid jobs and about $90 \%$ of their employees are women. According to European Commission Report (2017), manufacturing companies in Albania have a high impact on exports as well. In 2015, textiles, minerals, fuel and electricity counted for about $37 \%$ of total annual exports.

There are several reasons bringing a manufacturing company to demise, such as: a decrease in profitability, unfavourable market conditions, fierce competition, technological development, and more. The Albanian manufacturing industry has been operating for more than one decade in the framework of a highly informal economy, leading therefore to uncontrolled earnings and rentability. Starting from 2015, a new tax system and formalization reform took place. This caused the bankruptcy of most of the small manufacturing companies, due to the fact that they could not support their operations under the new fiscal system, which lowered their profitability.

According to Musta (2018), as a consequence of the 2015 reform, around 17.000 SMEs went bankrupt, and one year later the number rose to approximately 23.000 companies. A considerable share of the failed companies were manufacturers. This effect wasn't easily noticeable, because as almost 40.000 companies failed, a large number of new companies were created. 


\section{Literature review}

Bankruptcy is a global problem widely perceived to damage the entire economy (Kaufman, 1996). If bankruptcy could be expected with affordable precision ahead of time, managers and investors of companies may have the possibility to take action to secure their companies, reduce risk and loss of business and perhaps even avoid bankruptcy itself. Companies have experienced bankruptcy throughout the course of history. It results in financial and economic harm to creditors, investors and most importantly, to the economy in general. Therefore, it would be very useful if we would be able to predict which firms are vulnerable to the bankruptcy phenomena. For these reasons and more, bankruptcy has been a topic of study for researchers and students alike, with a particular focus on the predictability of such event (Paolone \& Pozzoli, 2017).

As many authors point out, "failure and bankruptcy are a natural and inescapable part of business" (Bell \& Scott, 2011; Walsh \& Bartunek, 2009). Weick considers bankruptcy "an organizational event that impacts the lives and livelihood of many-especially the people inhabiting and constructing the dying organization" (1995).

Companies have an economic cycle of life, which is dynamic and evolutive by nature. In most cases, crisis is preceded by a phase of decline. The decline of a company can be determined by a variety of factors. According to Damodaran (2009) these factors are: Stagnant or declining revenues, shrinking/negative margins, big payouts, asset divestures, financial leverage.

Corporate crisis can be seen as a worsement of the decline. Crisis starts when the business is unable to generate value, consequently decreasing the overall value of the entity (James, 2010). Many authors make a distinction between internal and external crisis. The aim of this distinction is to make the identification of the origin and causes of the crisis easier, whether it is specific to the company or more closely related to the market conditions and other exogenous elements.

Empirical studies on the matter indicate that it is impossible to attribute more overall importance to internal or external factors in determining the financial distress circumstance of a certain subject (Andrade \& Kaplan, 1998). Usually, there are multiple causes of the decline and the effective solutions cover a variety of intervention areas. A company's crisis may lead to a financial and/or economic distress. In general terms, distress exists when the company's equilibrium can't be reached under the current situation and if other actions are not taken, the firm is naturally destined to cease its operations (Pozzoli \& Paolone, 2017).

Many authors use the terms economic distress and financial distress as interchangeable. Others, like (Kahl, 2002), provide sound empirical evidence of no direct relation between the two. Anyway, it is generally accepted that economic distress usually leads to financial distress, considering there is no contribution from stockholders. Alternatively, a firm can be financially distressed even while being economically healthy. A firm can be considered as economically distressed when "the net present worth of the troubled company's business as a going concern is less than the value of the assets broken up and sold separately" (Nigam \& Boughanmi, 2017). A logical consequence of this would be the liquidation of the firm.

The natural and most likely outcome of financial distress is bankruptcy (Geng et al, 2015). Through this connection, the economic/financial concept of financial distress in translated into the juridical regime of bankruptcy. In some cases, firms will try to sell parts of their assets, make ownership changes, and even ask for part of the current obligations to be forgiven by the creditors. However, generally, bankruptcy leads to total liquidation, causing the demise of the affected firm.

Even though bankruptcy is considered as the main instrument which guarantees the reallocation of the manufacturing tools from the inefficient companies to the efficient and thriving ones, at times, it isn't considered the best solution to a company's crisis, because the disruptive ceasing of the operations and economic activity of a certain company may prevent giving back resources to the community.

\section{Methodology and Empirical analysis}

The Altman's Multivariate Analysis (1968) commonly known as the Altman Z-Score, is arguably the most notable and broadly used bankruptcy prediction model by researches and practitioners. The empirical analysis of this dissertation is based on a revised version of this model (1993), better suited for private companies.

Altman developed a statistical method called the MDA, multiple discriminant analysis, which derived from a linear combination of 5 financial ratios out of 22 in total, to discriminate at best between bankrupt and non-bankrupt companies. The MDA technique was subsequently utilized by many authors: Deakin (1972); Blum (1974); who tried to widen the framework created by Altman by adding new financial ratios to the model or by using a larger database. 
The multiple discriminant analysis produces a set of discriminant coefficient, which are applied to the company's ratios, by so producing a final score (the Z-Score) classifying it as bankrupt or non-bankrupt. The final model, containing the 5 ratios which discriminate at best according to Altman:

$$
\begin{aligned}
& \text { (1) } Z-\text { Score }=0.012 X 1+0.014 X 2+ \\
& 0.033 X 3+0.006 X 4+0.999 X 5
\end{aligned}
$$

Where:

$\mathrm{Z}$ is the value used to classify companies as bankrupt or non-bankrupt

$\mathrm{X} 1=$ Working capital over total assets

$\mathrm{X} 2=$ Retained earnings over total assets

X3 $=$ Earnings (before taxes and interests) over total assets

$\mathrm{X} 4=$ Market value of equity over book value of total debt

$\mathrm{X} 5=$ Sales over total assets.

A Z-Score > 2.99 means the company is safe (nonbankrupt)

A Z-Score $<1.81$ means the company has failed (bankrupt)

A Z-Score between these two values puts the selected company in the grey area, or zone of ignorance.

In our analysis, a later on revised model by Altman better suited for private companies (1993) is used in order to predict financial distress and bankruptcy in the Albanian manufacturing sector. The reason for this is that all Albanian companies are private and so this model will supposedly have a higher power of prediction.

\section{1 Methodology}

In order to analyze the effectiveness of the Altman Z- score model in predicting financial distress and bankruptcy in the Albanian manufacturing companies, the following steps are taken:

Step 1: The selection of the prescribed variables from Altman Z-Score model, which will be used to predict future bankruptcy. The ratios which, according to Altman, are the best in discriminating between failed and non-failed companies have been selected:

Liquidity. We will utilize the Working Cap/Total Assets index.

Profitability. We will use the Retained Earnings/Total Assets index.

Operating Efficiency. We will use the Operating Profit/Total Assets index.
Leverage. We will use Total Financial Debts (Book Value of Equity)/Total Equity index.

Competition/Asset Turnover. The ratio we will use is proxied by Total Sales Revenue/Total Assets.

Step 2: A dataset containing 204 active companies and 163 failed companies is taken from the National Register of Companies 2018.

This Register was provided by the NBC (National Business Centre) by specific request and a confidentiality agreement was signed.

The data is provided by an annual self-declaration process of all national firms. All the considered firms are part of the manufacturing industry. More specifically, some of the specializations are: construction-material manufacturing, production of pesticides, footwear manufacturing, production of soft drinks, cement manufacturing, production of furniture, flour milling, pharmaceutical manufacturing.

Based on the identifying number of each subject (NIPT), the required data have been extracted for each company from the balance sheets of 2015-2016 for the variables: Working Capital; Retained Earnings; Operating Profit; Total Financial Debts; Total Equity; Total Sales Revenue and Total Assets. Then, all the indicators involved in Altman's Z-

Score model adapted to private companies (1993) have been calculated:

(2) Z-Score $=0.717$ Working capital/total assets +0.847 Retained earnings/total assets +3.107 Operating profit $($ EBIT)/total assets +0.420 Book value of Equity/total liabilities +0.998 sales revenues/total assets

Although all businesses have a legal obligement to report and provide the required data to the NBC, from our observation, many balance sheet declarations are empty or suffer from a major lack of data, making it considerably hard to gather qualitative information and perform empirical studies. Despite the reform for economic formalisation in 2015, still some of the companies in Albania fail to declare their true financial data in their annual statements. Hence, some of variables used in this study, may not represent the true financial situation of these companies.

Step 3: Based on the balance sheets data of 2015 (concerning 2015 and reported in 2016), all the ZScore values have been calculated for the Altman Model to analyze if this model can be successfully used to predict bankruptcy in the case of the manufacturing sector in Albania. 
Step 4: Finally, a Logistic Regression Model is proposed in order to better predict the risk of financial distress and bankruptcy in the Albanian manufacturing industry.

\subsection{Data Analysis}

From the 2015 balance sheets of the selected manufacturing companies, the values of all the ratios involved in Z-Score model have been extracted.

Below are presented the tables of descriptive statistics for the ratios divided separately for Active and Failed companies.

Table 1: Descriptive statistics for the ratios for Active Companies (year 2015)

\begin{tabular}{|c|c|c|c|c|c|}
\hline & \multicolumn{5}{|c|}{ Group: Active Companies } \\
\cline { 2 - 6 } Ratio & Obs & Mean & Min & Max & $\begin{array}{c}\text { Standard } \\
\text { Deviation }\end{array}$ \\
\hline $\begin{array}{c}\text { Working } \\
\text { capital/Total } \\
\text { assets }\end{array}$ & 204 & -0.13 & -48 & 7.56 & 3.494 \\
\hline $\begin{array}{c}\text { Retained } \\
\text { earnings/Total } \\
\text { assets }\end{array}$ & 204 & 0.13 & -1.2 & 4.498 & 0.551 \\
\hline $\begin{array}{c}\text { Operating } \\
\text { profit } \\
\begin{array}{c}\text { EBIT)/Total } \\
\text { assets }\end{array}\end{array}$ & 204 & 0.154 & -1.2 & 7.698 & 0.689 \\
\hline $\begin{array}{c}\text { BVE/Total } \\
\text { liabilities }\end{array}$ & 204 & -5.23 & 1407 & 82.69 & 99.75 \\
\hline $\begin{array}{c}\text { Sales } \\
\text { revenues/Total } \\
\text { assets }\end{array}$ & 204 & 1.118 & 0 & 33.64 & 2.96 \\
\hline
\end{tabular}

Table 2: Descriptive statistics for the ratios for Failed Companies (year 2015)

\begin{tabular}{|c|c|c|c|c|c|}
\hline & \multicolumn{5}{|c|}{ Group: Active Companies } \\
\cline { 2 - 6 } Ratio & Obs & Mean & Min & Max & $\begin{array}{c}\text { Standard } \\
\text { Deviation }\end{array}$ \\
\hline $\begin{array}{c}\text { Working } \\
\text { capital/Total } \\
\text { assets }\end{array}$ & 163 & -0.38 & -65 & 42.57 & 6.49 \\
\hline $\begin{array}{c}\text { Retained } \\
\text { earnings/Total } \\
\text { assets }\end{array}$ & 163 & -0.51 & -54 & 6.511 & 4.67 \\
\hline $\begin{array}{c}\text { Operating } \\
\text { profit } \\
\text { (EBIT)/Total } \\
\text { assets }\end{array}$ & 163 & -0.36 & -54 & 6.51 & 4.53 \\
\hline $\begin{array}{c}\text { BVE/Total } \\
\text { liabilities }\end{array}$ & 163 & 6.44 & -179 & 338 & 38.49 \\
\hline $\begin{array}{c}\text { Sales } \\
\text { revenues/Total } \\
\text { assets }\end{array}$ & 163 & 1 & 0 & 21.34 & 2.56 \\
\hline
\end{tabular}

In Table 3, the Ratios and Coefficients of the Altman Z-Score model are presented.

Table 3: The revised Altman Z-Score Model

\begin{tabular}{|c|c|l|}
\hline \multicolumn{3}{|c|}{ Private Companies } \\
\hline Coefficient & Ratio & Variable \\
\hline 0.717 & $\begin{array}{c}\text { Working capital/Total } \\
\text { Assets }\end{array}$ & $\mathrm{X} 1$ \\
\hline 0.847 & $\begin{array}{c}\text { Retained earnings/Total } \\
\text { Assets }\end{array}$ & $\mathrm{X} 2$ \\
\hline 3.107 & $\begin{array}{c}\text { Operating profit/Total } \\
\text { Assets }\end{array}$ & $\mathrm{X} 3$ \\
\hline 0.42 & $\begin{array}{c}\text { BVE/Total Liabilities } \\
\text { Assets }\end{array}$ & $\mathrm{X} 4$ \\
\hline 0.998 & $\begin{array}{c}\text { Sales Revenues/Total } \\
\text { The Model: }\end{array}$ & $\mathrm{X} 5$ \\
\hline \multicolumn{3}{|c|}{$\mathrm{Z}=0.717 \mathrm{X} 1+0.847 \mathrm{X} 2+3.107 \mathrm{X} 3+0.420 \mathrm{X} 4+0.998 \mathrm{X} 5$} \\
\hline
\end{tabular}

First, we started to apply the Z-Score to our sample of active (non-bankrupt) companies.

Based on the $Z$ values calculated from the model, we divided the active companies from the initial database of 2018 as Bankrupt, Non-Bankrupt and companies in grey area according the following classification:

Z-Score model adapted for private companies:

- Z-Score of $<1.23$ represents a company in distress.

- Z-Score between 1.23 and 2.9 represents the "caution" zone or companies in grey area.

- Z-Score of over 2.9 represents a company with a safe balance sheet.

The tables below present the power of prediction within 2 years of Altmans' model in the case of active companies.

Table 4: Power of prediction in 2 years (Active Companies case)

(Altman's Model, 1993)

\begin{tabular}{|c|l|c|c|}
\hline & $\begin{array}{l}\text { Altman } \\
\text { model, } \\
\text { Active } \\
\text { Companies }\end{array}$ & Obs & $\%$ \\
\hline $\begin{array}{c}\text { Power of } \\
\text { prediction } \\
\text { in 2-years }\end{array}$ & $\begin{array}{l}\text { Companies at } \\
\text { risk }\end{array}$ & & \\
\hline & $\begin{array}{l}\text { Companies } \\
\text { in grey area }\end{array}$ & 41 & $48.5 \%$ \\
\hline & $\begin{array}{l}\text { Companies } \\
\text { not at risk }\end{array}$ & 64 & $20.1 \%$ \\
\hline & Total & 204 & $100 \%$ \\
\hline
\end{tabular}


The Altman Z-Score Model is found to be accurate in $31.4 \%$ of the cases and not significant in $48.5 \%$ of them since 99 out of 204 Active Companies have found to be "At Risk" instead of "Not at risk" (Type II error - classifying non-bankrupt as bankrupt is $48.53 \%)$.

The same procedure is followed for failed companies.

Table 5: Power of predicting in 2-years (Failed Companies case)

(Altman's Model, 1993)

\begin{tabular}{|l|l|c|c|}
\hline & $\begin{array}{l}\text { Altman model, } \\
\text { Failed Companies }\end{array}$ & Obs & $\%$ \\
\hline $\begin{array}{l}\text { Power of } \\
\text { prediction } \\
\text { in 2-years }\end{array}$ & Companies at risk & 79 & $48.5 \%$ \\
\hline & $\begin{array}{l}\text { Companies in grey } \\
\text { area }\end{array}$ & 26 & $16 \%$ \\
\hline & $\begin{array}{l}\text { Companies not at } \\
\text { risk }\end{array}$ & 58 & $35.5 \%$ \\
\hline & Total & 163 & $100 \%$ \\
\hline
\end{tabular}

The Altman Z-score Model (1993) is found to be accurate in $48.5 \%$ of the cases and not significant in $35.5 \%$ of them since 58 out of 163 Failed Companies have found to be "Not at Risk" instead of "At Risk" (Type I error - classifying a Bankrupt firm as nonbankrupt is $35.58 \%$ )

From observing the results, we notice that overall, the Altman Z-Score Model has a weak ability to predict bankruptcy in the Albanian manufacturing industry.

Considering the low predictive power of the considered model, a more suitable model for our case study will be proposed. The suggested model is a Logistic Regression, which is expected to increase the rate of accuracy in predicting bankruptcy.

\subsection{The Logistic Regression Model}

The Logistic Regression Model is used when the dependent variable is a binary or dichotomous variable. The two values taken by dependent variable, are coded 0 and 1 . The desired event is coded with 1 and the other with 0 . In a model where the dependent variable is quantitative, the objective is to estimate the expected value or mean value of the dependent variable given the value of the independent variables, while in models where the dependent variable is qualitative, the objective is to estimate the probability that the event $\mathrm{y}=1$ will happen. That's the reason why the dependent qualitative response regression models are known as Probability Models.
The two well-known probability models are:

1. The Logit Model

2. The Probit Model

In the Logit Model, the probability that the desired event will occur is:

$P\left(y=1 \mid X_{i}\right)=\frac{e^{\beta_{0}+\beta_{1} X_{1}+\cdots+\beta_{n} X_{n}}}{1+e^{\beta_{0}+\beta_{1} X_{1}+\cdots+\beta_{n} X_{n}}}$

When the values of $\beta_{0}+\beta_{1} X_{1}+\cdots+\beta_{n} X_{n}$ range from $-\infty$ till $+\infty$, the values of probability range from 0 to 1 .

From equation (1), we can write:

$\operatorname{Ln}\left(\frac{p_{i}}{1-p_{i}}\right)=\beta_{0}+\beta_{1} X_{1}+\cdots+\beta_{n} X_{n}$

This model is called the Logit Model.

So, logit $\left(p_{i}\right)=\beta_{0}+\beta_{1} X_{1}+\cdots+\beta_{n} X_{n}$

The ratio $\frac{p_{i}}{1-p_{i}}$ is called the Odds Ratio in favor of event $\mathrm{y}=1$.

To estimate the parameters in equation (4), the Maximum Likelihood Estimation Method with sample data is used.

The McFadden $R^{2}$ is, ranging from 0 to 1 , is used as a measure of Goodness of Fit. The HosmerLemeshow is also a commonly used measure of Goodness of Fit based on the Chi-square test. If the predicted probability of the event $y=1$ is greater than 0.5 , we classify it as 1 , and if less than 0.5 , we classify it as 0 .

In equation (4), the parameters are interpreted as the effect of the independent variables on the Logit Function, where the value of one independent variable changes with 1 unit and the other independent variables are taken as constant.

\subsubsection{The Logistic Model for the manufacturing industry}

As the Altman Z-score model was found to have a low predictive power in the Albanian manufacturing sector case, we have decided to put forward a Logistic Regression Model employing 5 ratios, based on data taken from 367 manufacturing companies in 2019 from the Albanian National Business Centre.

In Table 11, a sample representation of the dataset is made, the first column indicating the status of each company, marked as 1 if the company is Active and as 0 if the company is Failed. 
Table 6: Ten companies chosen randomly from the dataset, Excel spreadsheet.

\begin{tabular}{|c|c|c|c|c|c|c|}
\hline $\begin{array}{l}\text { Com } \\
\text { pany }\end{array}$ & $\begin{array}{l}\text { Sta } \\
\text { tus }\end{array}$ & $\begin{array}{l}\text { Liqui } \\
\text { dity }\end{array}$ & $\begin{array}{l}\text { Profita } \\
\text { bility }\end{array}$ & $\begin{array}{l}\text { Opera } \\
\text { ting } \\
\text { Effici } \\
\text { ency }\end{array}$ & $\begin{array}{l}\text { Leve } \\
\text { rage }\end{array}$ & $\begin{array}{l}\text { Compe } \\
\text { tition }\end{array}$ \\
\hline A & 1 & -0.08 & -0.167 & -0.17 & -2.87 & 0.1978 \\
\hline B & 1 & 0.508 & 0.0269 & 0.179 & 2.019 & 0.4364 \\
\hline $\mathrm{C}$ & 1 & -0.75 & 0.1212 & 0.121 & -3.37 & 0.6643 \\
\hline D & 1 & 0.937 & 0.1574 & 0.185 & 1.024 & 0.4587 \\
\hline $\mathrm{E}$ & 1 & 0.238 & 0.8822 & 1.014 & 1.321 & 3.064 \\
\hline $\mathrm{F}$ & 1 & -0.55 & 0.0435 & 0.051 & 6.993 & 0.3587 \\
\hline G & 1 & 7.56 & 0.3780 & 0.458 & 1.064 & 10.135 \\
\hline $\mathrm{H}$ & 1 & 0.139 & 0.0567 & 0.06 & 3.611 & 0.2597 \\
\hline I & 1 & 0.573 & 0.1621 & 0.162 & 2.164 & 2.5584 \\
\hline $\mathrm{J}$ & 1 & -0.01 & 0.0008 & 0.061 & $\begin{array}{c}- \\
1406\end{array}$ & 0.7603 \\
\hline
\end{tabular}

Eviews 6 has been used in order to find the estimated equation for the Logit Model. The table containing the output data is shown below. The selected five ratios are evidenced in the first column; in the second column we have the estimated values for the parameters; in the third column the respective standard errors; in the fourth column the p-values; in the fifth column the values of the z-statistic for individual significance tests and in the last column the $e^{\beta}$ values are presented.

Table 7: Goodness of fit of the model

\begin{tabular}{|l|c|}
\hline LR statistic & 11.78186 \\
\hline Prob (LR statistic) & 0.037902 \\
\hline McFadden R-squared & 0.064 \\
\hline
\end{tabular}

Table 8: Logistic regression - output variables

\begin{tabular}{|l|l|l|l|l|l|}
\hline Ratios & $\begin{array}{l}\text { Estimat } \\
\text { ed b }\end{array}$ & S.E & $\begin{array}{l}\text { Significa } \\
\text { nce }\end{array}$ & $\begin{array}{l}\text { Z- } \\
\text { statist } \\
\text { ic }\end{array}$ & $\begin{array}{l}\text { EX } \\
\mathrm{P} \mathrm{b}\end{array}$ \\
\hline $\begin{array}{l}\text { Working } \\
\text { Capital/Tot } \\
\text { al Assets }\end{array}$ & -0.03 & 2.07 & 0.02 & -0.79 & 0.97 \\
\hline $\begin{array}{l}\text { Retained } \\
\text { Earnings/T } \\
\text { otal Assets }\end{array}$ & 0.23 & 0.12 & 0.024 & 1.303 & 1.25 \\
\hline $\begin{array}{l}\text { Operating } \\
\text { Profit/Total } \\
\text { Assets }\end{array}$ & -0.001 & 0.18 & 0.997 & -0.01 & 0.99 \\
\hline $\begin{array}{l}\text { Book value } \\
\text { of } \\
\text { Equity/Tot } \\
\text { al Equity }\end{array}$ & -0.007 & 0.01 & 0.023 & -1.48 & 0.99 \\
\hline $\begin{array}{l}\text { Total Sales } \\
\text { Revenue/T } \\
\text { otal Assets }\end{array}$ & 0.022 & 0.05 & 0.653 & 0.45 & 1.02 \\
\hline Constant & 0.22 & 0.12 & 0.054 & 1.927 & 1.25 \\
\hline
\end{tabular}

From Table 8, we can see that the variables: Operating Profit/Total Assets and Total Sales Revenue/Total Assets, are not significant since the p-values are respectively 0.997 and 0.653 . In the Individual significance test, the probability 0.05 is the separation point between significant and nonsignificant. Consequently, we have taken out these 2 variables and re-estimated the parameters. The new output is reported below.

Table 9: Logistic regression 1- The New Logit

\begin{tabular}{|l|l|c|c|c|c|}
\hline Ratios & $\begin{array}{l}\text { Estimat } \\
\text { ed b }\end{array}$ & S.E & $\begin{array}{l}\text { Significa } \\
\text { nce }\end{array}$ & $\begin{array}{l}\text { Z- } \\
\text { statist } \\
\text { ic }\end{array}$ & $\begin{array}{l}\text { EX } \\
\text { P b }\end{array}$ \\
\hline $\begin{array}{l}\text { Working } \\
\text { Capital/Tot } \\
\text { al Assets }\end{array}$ & -0.04 & 0.02 & 0.041 & -1.7 & 0.9 \\
\hline $\begin{array}{l}\text { Retained } \\
\text { Earnings/T } \\
\text { otal Assets }\end{array}$ & 0.24 & 0.14 & 0.05 & 1.64 & 1.3 \\
\hline $\begin{array}{l}\text { Book value } \\
\text { of } \\
\text { Equity/Tota } \\
\text { l Equity }\end{array}$ & -0.008 & 0.01 & 0.013 & -2.2 & 0.9 \\
\hline Constant & 0.26 & 0.13 & 0.023 & 2.00 & 1.3 \\
\hline
\end{tabular}

Table 10: Goodness of fit of the new model

\begin{tabular}{|l|l|}
\hline LR statistic & 11.53 \\
\hline Prob (LR statistic) & 0.009 \\
\hline McFadden R-squared & 0.097 \\
\hline
\end{tabular}


From Table 9, we can conclude that all variables are significant, so the proposed logistic equation is:

$$
\mathbf{P}\left(\mathbf{Y}=\mathbf{1} \mid \mathbf{X}_{\mathbf{i}}\right)=
$$

$\mathrm{e}^{0.26-0.04 \text { Liquidity+0.24 Prof itability-0.008 Leverage }}$

$\overline{1+\mathrm{e}^{0.26-0.04} \text { Liquidity+0.24 Profitability-0.008 Leverage }}$

Or: $\operatorname{logit}\left(p_{i}\right)=0.26-0.04$ Liquidity +

0.24 Profitability -0.008 Leverage

Where the $p_{i}$ is the estimated probability that the company is active.

Table 11: Expectation-Prediction Evaluation for Binary Specification

\begin{tabular}{|c|c|c|c|}
\hline \multicolumn{3}{|c|}{ Estimated Equation } & \\
\hline & Dep $=0$ & Dep $=1$ & Total \\
\hline $\mathrm{P}(\mathrm{Dep}=1)<=C$ & 13 & 5 & 18 \\
\hline$P($ Dep $=1)>C$ & 150 & 199 & 349 \\
\hline Total & 163 & 204 & 367 \\
\hline Correct & 13 & 199 & 212 \\
\hline$\%$ Correct & 7.98 & 97.55 & 57.77 \\
\hline$\%$ Incorrect & 92.02 & 2.45 & 42.23 \\
\hline Total Gain* & 7.98 & -2.45 & 2.18 \\
\hline Percent Gain** & 7.98 & NA & 4.91 \\
\hline
\end{tabular}

From the Expectation-Prediction Evaluation for Binary Specification, we see that overall, the estimated model correctly predicts $57.77 \%$ of the observations $(7.98 \%$ of the Dep $=0$ and $97.55 \%$ of the Dep=1 observations). Something worth noting, is that despite the relatively good overall prediction power and excellent prediction accuracy in the case on non-bankrupt companies, this model appears not to be very reliable in the case of bankrupt companies (Type I error).

How to use the New Model?

Now, we will demonstrate how to use this new bankruptcy prediction model. Let's suppose the three ratios for a random Albanian manufacturing company are:

1. Liquidity -0.24

2. Profitability -0.88

3. Leverage -1.32

Now, let's put the values in the equation:

(6)

$\mathrm{Q}=0.26-0.04$ Liquidity +0.24 Profitability 0.008 Leverage

So,

$\mathrm{Q}=0.26-0.04 * 0.24+0.24 * 0.88-0.008 * 1.32$ $=0.451$
$\mathrm{P}\left(\mathrm{Y}=1\right.$ I $\left.\mathrm{X}_{\mathrm{i}}\right)=\frac{\mathrm{e}^{Q}}{1+\mathrm{e}^{Q}}=\frac{e^{0.451}}{1+e^{0.451}}=\mathbf{0 . 6 1}$

Companies are classified as bankrupt if their score is lower than 0.5 and as non-bankrupt if their score is above 0.5 .

According to our newly created model, this company is considered as non-bankrupt or "safe" because the estimated probability is 0.61 .

\section{Conclusions}

Albania faces a variety of economic, political and social challenges that should be handled with responsibility and precaution. The shift from a consumer-based to a production-based economy has to finally occur and some wise policies have to be implemented in order to foster stability and economic growth. A favorable business climate must be created aiming to promote young entrepreneurs, foreign investment and the further development of the existing companies. Furthermore, investments in technology and innovation are vital for the capability of Albanian firms to compete in international markets.

As of the manufacturing sector, one of the main issues is the unfair competition that many domestic companies are having with some shady importers. Better custom controls, the tackle of informality and some facilitations in the policies encircling this sector, would bring major benefits and further growth.

In the context of instability and future uncertainty, the need for an accurate financial distress and bankruptcy model arises to help managers, experts and administrators to better understand their financial positioning and future risks. This can oftentimes be very helpful and the implementation of proper measures, many firms may be saved, or at least the damages brought by the bankruptcy minimized.

The Altman Multivariate Analysis fails to accurately predict financial distress and bankruptcy in the Albanian manufacturing sector. This comes as no great surprise, considering the specific dynamics of this market and various problems, such as untruthful financial reporting and fiscal evasion.

The newly proposed model, the logistic regression, appears to work better in this framework. To conclude, we hope that the adoption of this model, especially when having accurate financial data, can help improve the overall performance of the country's manufacturing industry. 


\section{References:}

[1] Altman E.I., Financial ratios, discriminant analysis and the prediction of corporate bankruptcy, Journal of Finance, 23, 1968, pp. 589-609.

[2] Altman E.I., Corporate financial distress and bankruptcy: A complete guide to predicting and avoiding distress and profiting from bankruptcy. New York: Wiley \& Sons, 1993.

[3] Anamali A., Zisi A. and Shosha B., Albanian Apparel Industry and Its Characteristics of Development, Academic Journal of Interdiciplinary Studies, Vol. Nr.4, No.3. MCSER Publishing, 2015, Rome, Italy.

[4] Andrade G., \& Kaplan S. N., How costly is financial (not economic) distress? Evidence from highly leveraged transactions that became distressed, The Journal of Finance, 53(5), 1998, pp. 1441-1494.

[5] Bell E., \& Scott T., Beyond letting go and moving on: New perspectives on organizational death, loss and grief, Scandinavian Journal of Management, 27(1), 2011, pp. 1-10.

[6] Blum M., Failing company discriminant analysis, Journal of Accounting Research 12(1), 1974, pp. 1-25.

[7] Cania L., Nexhipi O. and Korsita B., "The Role of SMEs in Economic Development - An Empirical Study of Albania", Paper presented at 13th International Conference of ASECU, 2016.

[8] Daekin E. D., A discriminant analysis of predictors of business failure, Journal of Accounting Research, 10, 1972, pp. 167-180.

[9] Damodaran A., Valuing distress and declining companies, New York: Stern School of Business, 2009.

[10] European Commission Report (2017). Retrieved from: https://ec.europa.eu/neighbourhoodenlargement/sites/near/files/albania_sba_fs_20 17.pdf

[11] Geng R., Indrahil B., \& Xi,C., Prediction of financial distress: An empirical study of listed Chinese companies using data mining, European Journal of Operating Research, 241(1), 2015, pp. 236-248.

[12] James H., The creation and destruction of value: The globalization cycle, Cambridge, MA: Harvard University Press, 2010.

[13] Kahl M., Economic distress, financial distress, and dynamic liquidation, The Journal of Finance, 57(1), 2002, pp. 135-168.
[14] Kaufman G.G., Bank Failures, Systematic Risk, and Bank Regulation, Cato Journal, Volume (16)1, 1996, pp. 17:45.

[15] Musta E., The impact of financing in business growth opportunities: the voluntary selfexclusion from lending phenomenon and the Islamic financing alternative, PHD Thesis, European University of Tirana, 2018.

[16] National Business Center (2019), Dataset of financial data regarding the manufacturing industry, Tirana, Albania.

[17] Nigam N., \& Boughanmi A., "Can innovative reforms and practices efficiently resolve financial distress?" Journal of Clear Production, 140, 2017, pp. 1860-1871.

[18] Paolone F. \& Pozzoli M., Corporate Financial Distress: A Study of the Italian Manufacturing Industry, Springer International Publishing AG, 2017

[19] Walsh I. J., \& Bartunek J., RESCUE AND RECOVERY: Members' experiences of organizational death and afterlife. In K. D. Elsbach, \& B. A Bechky (Eds), Qualitative organizational research: Best papers from the Davis Conference on qualitative research ( $\mathrm{pp}$. 221-251). Charlotte, NC: Information Age Publishing, 2009. 